\title{
Stem cuttings and substrates in Dovyalis asexual propagation
}

\author{
André Renato Rinaldi', Fabíola Villa ${ }^{*}$, Daniel Fernandes da Silva², Rafael Massahiro Yassue
}

'State University of Western Paraná, Marechal Cândido Rondon, PR, Brazil.

${ }^{2}$ Federal University of Lavras, Lavras, MG, Brazil

*Corresponding author, e-mail:fvilla2003@libero.it

\begin{abstract}
The objective of this study was to evaluate the asexual propagation of Dovyalis, through the use of substrates and cuttings. Three experiments were conducted in Marechal Cândido Rondon, Paraná State, Brazil, and the first experiment consisted of three removal positions of the cuttings (apical, middle and basal) x 4 Indole butyric acid (IBA) concentrations $\left(0 \mathrm{mg} \mathrm{L}^{-1}, 1000 \mathrm{mg} \mathrm{L}^{-1}\right.$, $2000 \mathrm{mg} \mathrm{L}^{-1}$ and $\left.3000 \mathrm{mg} \mathrm{L}^{-1}\right)$; the second experiment evaluated the number of leaves in the cuttings $(2,4$ and 6$) \times 3$ cutting sizes $(10,15$ and $20 \mathrm{~cm})$; and the third experiment evaluated four substrates for rooting. The experiment was carried out in a randomized blocks design, with the first in a $3 \times 4$ and the second in a 3x3 factorial, respectively, containing 4 repetitions of 15 cuttings. The third experiment consisted of 5 repetitions of 15 cuttings. After the IBA treatment, the cuttings were taken to rooting in sandy beds during 70 days. The agronomical variables were evaluated. Basal and middle cuttings resulted in root systems with better development. The use of $1666 \mathrm{mg} \mathrm{L}^{-1}$ of IBA favors the Dovyalis cuttings rooting. Cuttings with 15 and $20 \mathrm{~cm}$ with four leaves favors the Dovyalis vegetative propagation. Dovyalis cuttings develop better on substrates containing latosol and vermiculite.
\end{abstract}

Keywords: Dovyalis hebecarpa (Gardner) Warb., stem cutting, phytohormone, exotic fruit

\section{Introduction}

The dovyalis belongs to the family Salicaceae and Dovyalis genus (Sleumer, 1980) where stood out the Dovyalis caffra (Hook f. and Harv.) Warb., D. hispidula Wild., D. Iongispina (Harv.) Warb., D. Iucida Sim., D. macrocalyx (Oliv.) Warb., D. rotundifolia (Thunb.) Harv., D. zeyheri (Sond.) Warb., D. abyssinica (A. Rich) Warb. and mainly D. hebecarpa (Gardner) Warb., being the last one known as 'groselha-do-Ceilão' (Mendes Ferrão, 1999).

Dovyalis fruits are $2-3 \mathrm{~cm}$ in diameter, acidic flavor, orange to reddish-purple color, attractive and with excellent pulp yield, characteristics that make it mainly destined to the processing, such as the production of candies, juices, liquor and coloring (Silva et al., 2011).

For the commercial cultivation of dovyalis, it is necessary a homogeneous and uniform orchard, with the use of seedlings with phytosanitary quality. In this sense, the use of asexual propagation becomes a viable alternative (Almeida et al., 2007). The use of cuttings is a fast and inexpensive method, which allows the maintenance of the characteristics of plants of agronomic interest (Hartmann et al., 2011). In many species, cuttings of the apical part have shown better rooting than other parts of the plant, but their viability depends on root formation capacity, root system quality and 
favorable conditions during plant development (Fachinello et al., 2005).

Several factors can reduce the propagation efficiency by influencing the formation of roots in cuttings, such the matrix vigor, age and position of the branches used, presence of leaves and buds, type of cutting, season of the year, application of plant regulators, temperature, moisture, light and substrate (Hartmann et al., 2011).

In order to optimize the seedlings production, it is often necessary to use alternative materials, either due to the plants physical or physiological requirements, such as the use of substrates (Fernandes et al., 2006).

The choice of the material to compose a substrate should take into consideration the species to be cultivated, the material cost and its availability. Often, to meet all the mentioned aspects, it is necessary to use more than one material to compose a substrate (Kratz et al., 2013).

However, there is little information in literature regarding the dovyalis agronomic behavior (Alves, 2014). New areas for fruit cultivation are emerging in western Paraná state in Brazil, requiring more studies regarding the production of seedlings according to the edaphoclimatic conditions of this region, asexual propagation, internal and external factors that interfere in the rooting of cuttings and physicalchemical characteristics of the substrates. According to this, the objective of this study was to evaluate the asexual propagation of dovyalis in Marechal Cândido Rondon, PR, Brazil.

\section{Material and methods}

Three experiments were conducted in the seedlings nursery of the Nucleus of Experimental Stations (NEE), of the University of the West of Paraná State (Unioeste). The municipality of Marechal Cândido Rondon presents humid subtropical climate, with Cfa classification, according to Köppen (Caviglione et al., 2000).

The dovyalis plants originated from seeds of fruits harvested in a local orchard after two years of cultivation, germinated in polystyrene trays containing the HortMax® commercial substrate and transplanted when reached $20 \mathrm{~cm}$ in height to $14 \mathrm{~L}$ polypropylene pots, containing as substrate argissol + fine washed sand 1:2 ratio, v/v). The seedlings were kept in $50 \%$ shade nursery, on steel benches with daily manual watering and control of pests and diseases. In July, 2012, the seedlings with $80 \mathrm{~cm}$ of height were transplanted to the orchard of the Experimental Farm of the Unioeste University, spaced $5 \times 4 \mathrm{~m}$, when the fertilization of planting was performed. In October 2013, the branch cuttings of these plants were removed to perform the experiments I and II, which were evaluated after 70 days.

For the experiment I, 720 cuttings from three positions of the branches of the matrix plants were collected, being 240 cuttings of each position (apical, middle and basal), $15 \mathrm{~cm}$ long and containing 4 leaves. The cuttings were collected using gloves, as the dovyalis plants have many thick thorns. The total number of cuttings was divided into 4 groups of 60 cuttings, each group being treated with indolbutyric acid (IBA) concentrations: $0 \mathrm{mg} \mathrm{L}^{-1}, 1000 \mathrm{mg} \mathrm{L}^{-1}, 2000$ $\mathrm{mg} \mathrm{L}^{-1}$ and $3000 \mathrm{mg} \mathrm{L}^{-1}$.

The experiment was carried out in a randomized blocks design, in a $3 \times 4$ factorial scheme (3 cuttings positions $x 4$ IBA concentrations), containing 4 repetitions and 15 cuttings per repetition.

After the rooting period, laboratory evaluations of the experiment I were carried out. The analyzed variables were total number of shoots, average diameters of shoots (with the aid of a digital caliper), total number of roots (after washing), mean length of roots (using a millimeter ruler) and total shoot fresh biomass (with the aid of an analytical scale).

For experiment II, 540 woody cuttings were collected from the middle part of the dovyalis plants, being divided into 3 groups according to size $(10,15$ and $20 \mathrm{~cm})$, and the number of leaves/cutting: 2, 4 and 6 leaves. After the collection, the cuttings were immersed in $2000 \mathrm{mg} \mathrm{L}^{-1}$ IBA solution.

The experiment II was conducted in a randomized blocks design, in a $3 \times 3$ factorial scheme ( 3 cutting sizes $x$ number of cuttings), containing 4 repetitions and 15 cuttings per repetition.

Immediately after the IBA treatment, the 
cuttings of the experiments I and II were taken to rooting in a bed containing sterilized and washed fine sand as substrate under intermittent irrigation using micro-sprinklers, on every 30 minutes during the day, in a protected environment condition. The spacing used between the cuttings was $4 \mathrm{~cm}$ between rows $x 3 \mathrm{~cm}$ between cuttings.

After 70 days in the rooting bed, the agronomical variables of the experiment II were carried out, whose variables were total number of shoots, average shoot diameter (with the aid of a digital caliper), total number of roots (after washing) and average length of roots (using a millimeter ruler), total fresh root biomass and total roots and shoots dry biomass (in an oven at $60^{\circ} \mathrm{C}$, up to constant weight).

For the experiment III, 300 cuttings of the middle position of the dovyalis plants, with $15 \mathrm{~cm}$ in length and containing 4 leaves, were distributed in four different substrates, being 1 coconut fiber + Plantmax commercial substrate + Vermiculite of medium texture, 2 - latosol + medium texture vermiculite + washed fine sand, both in the proportion of $1: 1: 1, \mathrm{v} / \mathrm{v} / \mathrm{v}$ ), 3 - latosol + sand and 4 - latosol + vermiculite (the last two in the 1:1 proportion, $v / v)$. After the collection, the cuttings were immersed in a $2000 \mathrm{mg} \mathrm{L}^{-1}$ IBA solution. Immediately after treatment, cuttings were placed in plastic bags containing the respective substrates.

The experiment III was carried out in a randomized blocks design, containing 4 substrates, 5 repetitions and 15 cuttings per repetition, totaling 300 cuttings.

For the experiment III the number of roots, mean root length $(\mathrm{cm})$ and average number of shoots were evaluated.

The results obtained from the experiments were submitted to variance analysis, and the means compared by the Scott-Knott's test, at $5 \%$ of error probability, using the software Sisvar (Ferreira, 2011). The concentrations of indolebutyric acid were evaluated by regression analysis, with the coefficients being tested up to $5 \%$ of error probability by the t test.

\section{Results and Discussion}

Experiment I

It was possible to observe a significant interaction for the average number of shoots and average number of roots on dovyalis cuttings (Figures 1 and 2). Regarding shoots average diameter, significance was observed for the use of different IBA concentrations (Figure 3). For the variables average root length and fresh shoot biomass, significance was only observed for the shoot removal region (Table 1).

There was a significant interaction between IBA concentration and cuttings types for the average number of shoots, only in cuttings of dovyalis from the middle part of the matrix, with the best results observed using IBA 1250 $\mathrm{mg} \mathrm{L}^{-1}$, according to the equation obtained by the statistical data. A quadratic curve with a decrease up to $3000 \mathrm{mg} \mathrm{L}^{-1}$ was observed (Figure 1). This fall is probably due to auxin phytotoxicity, which was exogenous aaplied to dovyalis cuttings (Hartmann et al., 2011). For the other IBA concentrations and types of cuttings, no significant interaction was observed.

According to Nachtigal et al. (1994), one of the symptoms of phytotoxicity by high concentrations of IBA on cuttings during rooting is the leaf fall, mainly due to the formation abcision layer, which can be observed in the treatments in which the applied concentrations of the phytoregulator were larger, supporting the hypothesis of cuttings phytotoxicity at concentrations above $1250 \mathrm{mg} \mathrm{L}^{-1}$ of IBA. The cited authors verified such behavior in the rooting of 'araçazeiro' (Psidium Cattleyanum Sabine) cuttings, which can also be verified in mountain goats (Acca sellowiana Berg) rooting when treated with high IBA concentrations (Franzon ef al., 2004).

Higher number of buds was observed in blueberry cuttings, cultivar Powderblue, with the use of $1000 \mathrm{mg} \mathrm{L}^{-1}$ of IBA (Fischer et al., 2008). Similar results regarding phytotoxicity were observed by Campagnolo and Pio (2012) in blackberries stem cuttings, where a linear decrease in the number of shoots was observed, as the auxin concentrations tested increased.

This phytotoxicity to indolebutyric acid is due to hormonal imbalance when the cuttings are in contact with auxins. This imbalance lead to a spent of the cuttings reserves (which should be directed to the shoot structures formation) to root 


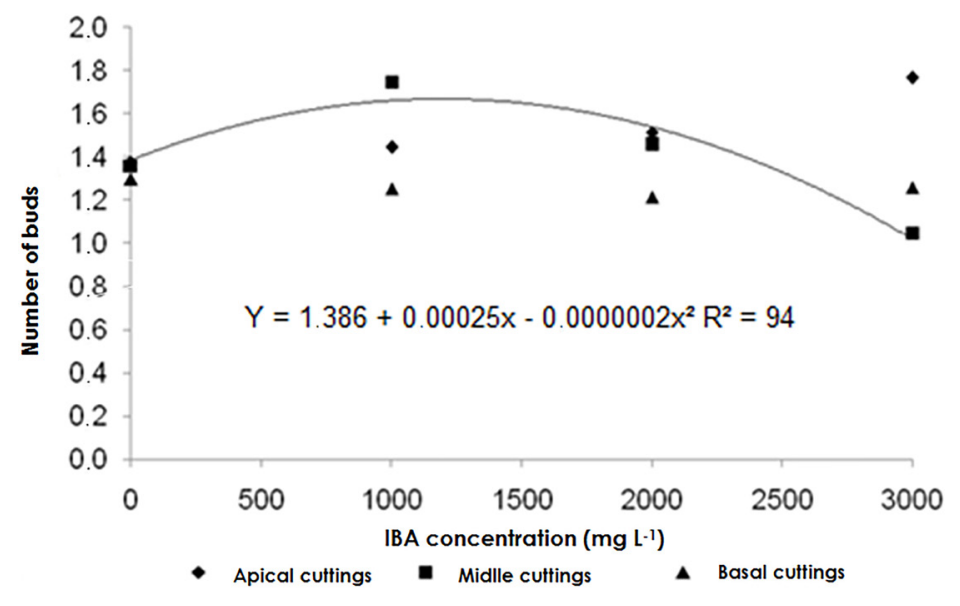

Figure 1. Average number of shoots in apical, middle and basal dovyalis cuttings, according to the use of indolbutyric acid (IBA) concentrations. Unioeste, Campus Marechal Cândido Rondon, PR, Brazil. 2016.

emission, after an adventitious rizogenesis (Lima et al., 2006).

Figure 2 shows a significant interaction for root number in dovyalis cuttings. In the analysis unfolding, it is possible to observe a linear regression between the region of the cutting where the cutting was obtained and the IBA concentrations. With an increase in phytormones concentrations, a linear increase in the number of roots in the cuttings was observed, where better results were observed in basal cuttings. IBA is a substance related to cell division. The direct relation between concentrations, number and length of roots is explained by the fact that there is an anticipation of the emission of root primordia in the auxin-treated cuttings, in accordance to

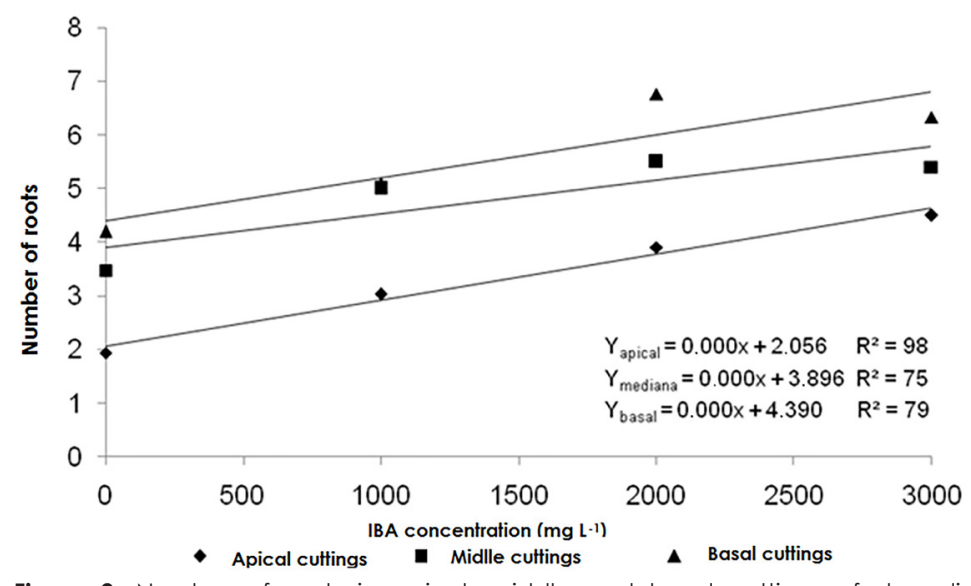

Figure 2. Number of roots in apical, middle and basal cuttings of dovyalis according to the indolebutyric acid (IBA) concentrations. Unioeste, Campus Marechal Cândido Rondon, PR, Brazil. 2016

the presented results (Wachowicz \& Carvalho, 2002).

The highest root emission when basal cuttings were used may have occurred due to the differentiated physiological conditions of basal cuttings, with higher concentrations of carbohydrates, nitrogenous substances, amino acids, auxins and phenolic compounds (Hartmann et al., 2011). All these factors in adequate proportions make the basal cuttings the most propitious to shoot adventitious roots, as observed in yellow passion fruit cuttings (Albuquerque Junior et al., 2013).

According to Lima etal. (2006), the choice of the branch and the position of the removal of the cuttings induce a great variation in the later development of the seedlings of fruit species, however, antagonistic results were observed in 'caramboleira' herbaceous stem cuttings (Bastos et al. 2006) and in dovyalis, Dovyalis hebecarpa (Almeida et al., 2007). This difference in the results with the use of auxin can be motivated by the 
time of exposure to the phytohormone. In the cited study, dovyalis cuttings were exposed during 5 seconds, probably not enough time for a satisfactory auxin fixation in the exposed tissues (Nava et al., 2014).

In figure 3 is possible to observe significance for IBA concentrations and shoot diameter. With the increase in IBA concentrations, an increase in shoot diameter up to the maximum point was observed, and the best results were obtained with the use of $1666 \mathrm{mg} \mathrm{L}^{-1}$ of IBA, according to the equation obtained by the statistical data.

The phytohormone is intrinsically linked to the root emission capacity of cuttings of fruit species. However, increased root vigor results in increased nutrient uptake and hydration by the stem, allowing the emission of shoot structures (Fischer et al., 2008). The same authors, in a study with blueberries cultivar Climax, observed higher shoot lengths using $1000 \mathrm{mg} \mathrm{L}^{-1}$ of IBA. The buds length is a variable directly related to diameter. With these variables is possible to obtain the real value of the cutting vigor (Souza \& Gentil, 2013).

Table 1 shows the average root length $(\mathrm{cm})$ and shoot fresh biomass $(\mathrm{mg})$ of dovyalis cuttings, according to the region where the cuttings were taken in the branch of the matrix plant.

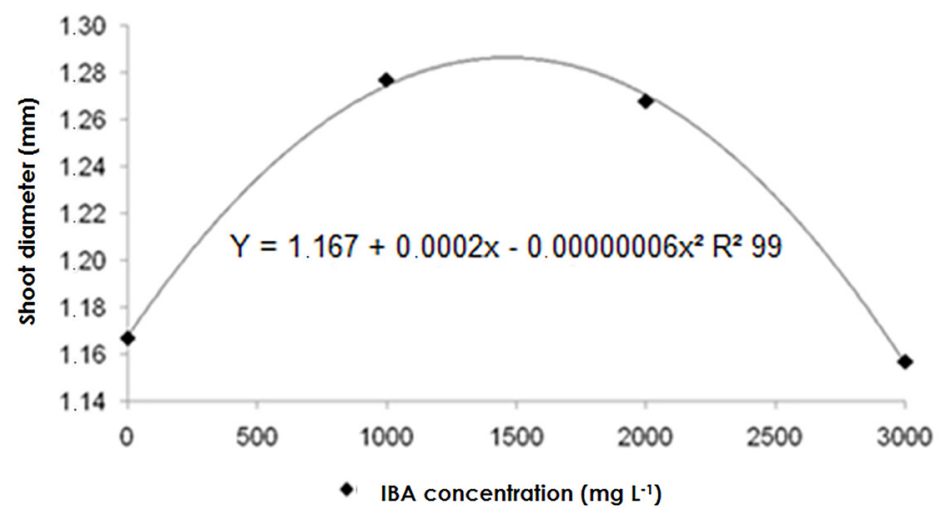

Figure 3. Shoot diameter in dovyalis cuttings according to the indolebutyric acid (IBA) concentrations. Unioeste, Campus Marechal Cândido Rondon, PR, Brazil. 2016.

Table 1. Average root length $(\mathrm{cm})$ and shoot fresh biomass $(\mathrm{mg})$ of dovyalis cuttings according to the region were the cuttings were obtained in the matrix plant. Unioeste, Campus Marechal Cândido Rondon, PR, Brazil. 2016.

\begin{tabular}{lcc}
\hline Cutting region & Average root length $(\mathrm{cm})$ & Shoot fresh biomass $(\mathrm{mg})$ \\
\hline Basal & $11.30 \mathrm{a}^{*}$ & $4.037 \mathrm{~b}$ \\
Median & $10.37 \mathrm{a}$ & $5.543 \mathrm{a}$ \\
Apical & $6.42 \mathrm{~b}$ & $2.761 \mathrm{c}$ \\
\hline $\mathrm{CV}(\%)$ & 28.05 & 18.32 \\
\hline *Different lowercase letters in the column: means are different according to Scott-Knott's test at 5\% of error probability.
\end{tabular}

For the average root length, better results were observed in cutting from basal and medium positions. For shoot fresh biomass, better results were verified in cuttings from the middle position (Table 1). There is a strict dependence between fresh and dry biomass (Ventura et al., 2014) and the latter is used as an indicative of the cuttings vigor (Paulus et al., 2014). Therefore, it can be affirmed that the shoot fresh biomass is also tied to the cutting vigor, where larger cuttings have more reserves (Lima et al., 2006).

For dovyalis, a trend can be observed in tissues with a high $\mathrm{C} / \mathrm{N}$ ratio (basal and middle cuttings) due to the higher amounts and better quality of emitted roots, corroborating with Paiva and Gomes (2005).

\section{Experiment II}

In Table 2 is possible to observe the significant interaction for cuttings length and number of leaves of dovyalis cuttings according to the number of buds.

Regarding the cuttings size, it was observed a significance for the average number of roots, roots fresh biomass and buds fresh biomass (Table 3). 
Table 2. Average number of shoots cording to the dovyalis cutting sizes and number of leaves. Unioeste, Campus Marechal Cândido Rondon, PR, Brazil. 2016.

\begin{tabular}{cccc}
\hline & \multicolumn{3}{c}{ Leaf number in dovyalis cuttings } \\
\hline Cuttings length $(\mathrm{cm})$ & 2 & 4 & 6 \\
\hline 10 & & Number of buds & \\
15 & $0.01 \mathrm{CA}$ & $0.01 \mathrm{aA}$ & $0.033 \mathrm{aA}$ \\
20 & $1.00 \mathrm{bA}$ & $0.433 \mathrm{aB}$ & $0.133 \mathrm{aB}$ \\
CV\% & $1.40 \mathrm{aA}$ & $0.133 \mathrm{aB}$ & $0.300 \mathrm{aB}$ \\
\hline *Different lowercase letters in the column: means are different according to Scott-Knott's test at $5 \%$ of error probability.
\end{tabular}

Table 3. Average number of roots, roots fresh biomass and buds fresh biomass of dovyalis cuttings. Unioeste, Campus Marechal Cândido Rondon, PR, Brazil. 2016.

\begin{tabular}{cccc}
\hline Cuttings size $(\mathrm{cm})$ & Average number of roots & Roots fresh biomass $(\mathrm{g})$ & Buds dry biomass $(\mathrm{mg})$ \\
\hline 10 & $3.293 \mathrm{a}^{*}$ & $2.500 \mathrm{~b}$ & $1.000 \mathrm{~b}$ \\
15 & $4.211 \mathrm{a}$ & $3.378 \mathrm{a}$ & $1.043 \mathrm{a}$ \\
20 & $5.189 \mathrm{a}$ & $2.843 \mathrm{~b}$ & $1.043 \mathrm{a}$ \\
\hline $\mathrm{CV}(\%)$ & 32.90 & 21.52 & 3.38 \\
\hline
\end{tabular}

It was observed a higher average number of shoots in dovyalis cuttings with $20 \mathrm{~cm}$ and containing two leaves. Larger and longer cuttings presented higher reserves amounts, which are used for sprouting and roots (Pizzatto et al., 2011). The presence of leaves is also a great influence factor for shoot sprouting, as they produce photoassimilates, among them soluble sugars, which are essential as an energy source for budding (Dias et al., 2011).

Vignolo et al. (2014) observed higher number and length of shoots in woody cuttings of blackberry cultivars with leaves. In a study with cuttings of olive cultivars, it was observed that the greater presence of leaves per cutting is inversely proportional to the percentage of cuttings sown, number of shoots per cutting and average shoots length. This fact is due to a greater stimulus in the shoots of the buds, as the removal of the leaves of the cutting takes place (Santoro et al., 2010).

For cutting size, no statistical difference for the average number of roots was observed, being possible to prepare dovyalis cuttings with 10, 15 and $20 \mathrm{~cm}$. Dovyalis cuttings with $15 \mathrm{~cm}$ presented larger root fresh biomass and with 15 and $20 \mathrm{~cm}$, greater dry biomass of shoots was observed. Cuttings with higher length tend to have more reserves, which are used after adventitious rhizogenesis, root system emission, as well as in aerial structures (Pizzatto et al., 2011). Similar results regarding the non-interaction between cutting size and number of roots were observed in 'jabuticabeira' cuttings (Sasso et al., 2010).

A significance is only observed in Table 4 for the number of leaves in dovyalis cuttings, where higher shoot diameter and dry biomass of roots were observed in cuttings with two and six leaves, respectively.

It is possible to verify a higher root biomass, variable that demonstrates the vigor of the roots (Paulus et al., 2014), in cuttings with six leaves. Similar results were obtained in 'caramboleira' cuttings by Bastos et al. (2009). The presence of leaves guarantees the survival of the cuttings, both by the synthesis of carbohydrates through photosynthesis, and by the auxins supply and other substances, which are important in the process of root formation and new leaves, stimulating the exchange activity and cell differentiation. The leaves are also intrinsically necessary for the rooting of cuttings, as they contribute to the soluble sugars among the produced photoassimilates (Nogueira et al., 2007).

The superior results for shoot/sprout diameter in cuttings with only two leaves can be explained by the stimulus that is given to the cutting for the production of photosynthetically active structures after the leaves removal (Santoro et al., 2010).

\section{Experiment III}

Significance was only observed for the 
Table 4. Shoots diameter and dry biomass of roots $(\mathrm{g})$ of dovyalis cuttings according to the number of leaves. Unioeste, Campus Marechal Cândido Rondon, PR, Brazil. 2016.

\begin{tabular}{ccc}
\hline Number of leaves & Shoot diameter $(\mathrm{cm})$ & Root dry biomass $(\mathrm{g})$ \\
\hline 2 & $1.253 \mathrm{a}^{*}$ & $1.286 \mathrm{~b}$ \\
4 & $1.063 \mathrm{~b}$ & $1.396 \mathrm{~b}$ \\
6 & $1.038 \mathrm{~b}$ & $1.530 \mathrm{a}$ \\
\hline $\mathrm{CV}(\%)$ & 16.93 & 11.68 \\
\hline *Different lowercase letters in the column: means are different according to Scott-Knott's test at 5\% of error probability.
\end{tabular}

average root length and average number of shoots (Table 5).

Better results for mean root length and average number of shoots on dovyalis cuttings were observed for the substrate containing latosol, vermiculite or sand (Table 5). According to Carvalho Junior et al. (2009) the well-formed root system increases the area of soil to be exploited, favoring the absorption of nutrients and water; In this way, the emission of roots in greater number and length, is fundamental to provide better seedlings development in the field.

Similar results for the two variables were also confirmed in 'papiraroba' (Piper mikanianum) cuttings at the Rio Grande do Sul state by Pescador et al. (2007). The vermiculite stands out among the other substrates in the cutting rooting due to its porosity and retention

Table 5. Average length of roots and average number of shoots in dovyalis cuttings according to the substrates used. Unioeste, Campus Marechal Cândido Rondon, PR, Brazil. 2016.

\begin{tabular}{ccc}
\hline Substrates & Root length $(\mathrm{cm})$ & Average number of shoots \\
\hline $\mathrm{CF}+\mathrm{CS}+\mathrm{V}$ & $21.85 \mathrm{~b}^{*}$ & $2.69 \mathrm{~b}$ \\
$\mathrm{LS}+\mathrm{V}+\mathrm{S}$ & $27.25 \mathrm{a}$ & $3.05 \mathrm{a}$ \\
$\mathrm{LS}+\mathrm{A}$ & $31.30 \mathrm{a}$ & $2.80 \mathrm{~b}$ \\
$\mathrm{LS}+\mathrm{V}$ & $28.00 \mathrm{a}$ & $3.05 \mathrm{a}$ \\
\hline $\mathrm{CV}(\%)$ & 18.48 & 13.63 \\
\hline "Different lowercase letters in the column: means are different according to Scott-Knott's test at 5\% of error probability. FC = coconut fiber, SC = comercial substrate - \\
Plantmax $\mathrm{V}$ = vermiculite, LS = latosol, A = fine washed sand.
\end{tabular}

Plantmax ${ }^{\Theta}, V=$ vermiculite $L S=$ latosol, $A=$ fine washed sand.

of water and nutrients capacity (Hartmann et al., $2011)$.

The fact that the coconut fiber and the commercial substrate did not presented satisfactory results in this study does not make it use unfeasible for dovyalis cuttings. However, adjustments should be made to the moisture conditions of the rooting environment and / or the mixture of components that result in greater drainage, since the coconut fiber, according to Malvestiti (2004), present a good water retention capacity.

With the accomplishment of these studies is possible to consider that new studies should be performed with dovyalis.

\section{Conclusions}

Cuttings from the basal and middle regions presented a well developed root system.

It is necessary to use $1666 \mathrm{mg} \mathrm{L}^{-1}$ of IBA in the rooting of dovyalis cuttings from basal and middle positions.

Cuttings with 15 and $20 \mathrm{~cm}$, containing 2 pairs of leaves are indicated for the vegetative propagation of dovyalis.

Was observed a better cutting development when substrates containing latosol and vermiculite in their formulation were used.

\section{References}

Albuquerque Junior, C.L., Danner, M.A., Kanis, L.A., Deschamps, C., Zanette, F., Farias, P.M. 2013. Enraizamento de estacas semilenhosas de maracujazeiro amarelo (Passiflora actinia Hook). Semina: Ciências Agrárias 34: 3663-3668.

Almeida, E.J., Jesus, N., Scaloppi Junior, E.J., Moreira, R.F.C., Martins, A.B.G. 2007. Dovyalis hebecarpa propagation by the use of cuttings. International Journal of Fruit Science 7: 1-7.

Alves, E.C. 2014. Clonagem por estaquia de ramos de Dovyalis hebecarpa e Dovyalis hebecarpa x D. abissinica. 33f. (Dissertação de mestrado) - Universidade Estadual Paulista, Jaboticabal, Brasil.

Bastos, D.C., Pio, R., Scarpare Filho, J.A., Almeida, L.F.P., Entelmann, F.A., Alves, A.S.R. 2006. Tipo de estaca e concentração de ácido indolbutírico na propagação da lichieira. Ciência \& Agrotecnologia 30: 97-102. 
Bastos, D.C., Scarpare Filho, J.A., Libardi, M.N., Pio, R. 2009. Estiolamento, incisão na base da estaca e uso do ácido indolbutírico na propagação da caramboleira por estacas lenhosas. Ciência \& Agrotecnologia 33: 313-318.

Campagnolo, M.A., Pio, R. 2012. Enraizamento de estacas caulinares e radiculares de cultivares de amoreira-preta coletadas em diferentes épocas, armazenadas a frio e tratadas com AIB. Ciência Rural 42: 232-237.

Carvalho Junior, W.G.O., Melo, M.T.P., Martins, E.R. 2009. Comprimento da estaca no desenvolvimento de mudas de alecrim-pimenta. Ciência Rural 39: 2199-2202.

Caviglione, J.H., Kiihl, L.R.B., Caramori, P.H.; Oliveira, D. Cartas climáticas do Paraná. 2000. Londrina: IAPAR, 1 CD-ROM. http://www.iapar. pr.gov.br/modules/conteudo/conteudo. php? conteudo=677 < Acesso em: 10 nov. 2015>.

Dias, J.P.T., Ono, E.O., Rodrigues, J.D. 2011. IBA e carboidratos no enraizamento de brotações procedentes de estacas radiciais de Rubus spp. Revista Brasileira de Fruticultura 33: 666-671.

Fachinello, J.C., Hoffmann, A., Nachtigal, J.C., Kersten, E., Fortes, G.R.L. 2005. Propagação de plantas frutíferas. Embrapa Informação Tecnológica, Brasília, Brasil. 221 p.

Fernandes, C., Corá, J.E., Braz, L. 2006. Desempenho de substratos no cultivo do tomateiro do grupo cereja. Horticultura Brasileira 24: $42-46$.

Ferreira, D.F. 2011 . SISVAR: a computer statistical analysis system. Ciência \& Agrotecnologia 35: 1039-1042.

Fischer, D.L.O., Fachinello, J.C., Antunes, L.E.C., Tomaz, Z.F.P., Giacobbo, C.L. 2008. Efeito do ácido indolbutírico e da cultivar no enraizamento de estacas lenhosas de mirtilo. Revista Brasileira de Fruticultura 30: 285-289.

Hartmann, H.T., Kester, D.E., Davies Junior, F.T., Geneve, R.L. 2011 . Plant propagation: principles and practices. 8ed. Englewood Clipps, New York, EUA. 880p.

Franzon, R.C., Antunes, L.E.C., Raseira, M.C.B. 2004. Efeito do AIB e de diferentes tipos de estaca na propagação vegetativa da goiabeiraserrana (Acca sellowiana Berg). Revista Brasileira de Agrociência 10: 515-518.

Kratz, D., Wendling, I., Nogueira, A.C., Souza, P.V. 2013. Propriedades físicas e químicas de substratos renováveis. Revista Árvore 37: $1103-$ 1113.

Lima, R.L.S., Siqueira, D.L., Weber, O.B., Cazetta,
J.O. 2006. Comprimento de estacas e parte do ramo na formação de mudas de aceroleira. Revista Brasileira de Fruticultura 28: 83-86.

Malvestiti, A.L. 2004. Propriedades e aplicações da fibra de coco na produção de mudas. In: Barbosa, J.G., Martinez, H.E.P., Pedrosa, M.W., Saiyama, M.A.N. (eds.) Nutrição e adubação de plantas cultivadas em substrato. UFV, Viçosa, Brasil. p.226-235.

Mendes Ferrão, J.E. 1999. Fruticultura tropical: espécies com frutos comestíveis. Instituto de Investigação Científica Tropical (IICT), Lisboa, Portugal. $621 \mathrm{p}$.

Nachtigal, J.C., Hoffmann, A., Kluge, R.A. Enraizamento de estacas semilenhosas de araçazeiro (Psidium cattleyanum Sabine) com o uso do ácido indolbutírico. 1994. Revista Brasileira de Fruticultura 16: 229-235.

Nava, G.A., Wagner, A.J., Mezzalira, E.J., Cassol, D.A., Alegretti, A.L. 2014. Rooting of hardwood cuttings of Roxo de Valinhos fig (Ficus carica L.) with different propagation strategies. Revista Ceres 61: 989-996.

Nogueira, A.M., Chalfun, N.N.J., Dutra, L.F., Villa, F. 2007. Propagação de figueira (Ficus carica L.) por meio de estacas retiradas durante o período vegetativo. Ciência \& Agrotecnologia 31: 914920.

Paiva, H.N., Gomes, J.M. 2005. Propagação vegetativa de espécies florestais. 3ed. Ed. UFV, Viçosa, Brasil. 46p.

Paulus, D., Valmorbida, R., Toffoli, E. 2014. Propagação vegetativa de Aloysia triphylla (L'Hér.) Britton em função da concentração de AIB e do comprimento das estacas. Revista Brasileira de Plantas Medicinais 16: 25-31.

Pescador, R., Voltoni, A.C., Girardi, C.G., Rosa, F.A.F. 2007. Estaquia de pariparoba do Rio Grande do Sul sob efeito do ácido indol-butírico em dois substratos. Scientia Agraria 8: 391-398.

Pizzatto, M., Wagner Júnior, A., Luckmann, D., Pirola, K., Cassol, D.A., Mazaro, S.M. 2011. Influência do uso de AIB, época de coleta e tamanho de estaca na propagação vegetativa de hibisco por estaquia. Revista Ceres 58: 487492.

Santoro, P.H., Mikami, A.Y., Souza, S.G.H., Roberto, S.R. 2010. Influência de folhas e lesões na base de estacas herbáceas no enraizamento de goiabeira da seleção 8501-9. Semina: Ciências Agrárias 31: 289-294.

Sasso, S.A.Z., Citadin, I., Danner, M.A. 2010. Propagação de jabuticabeira por estaquia. Revista Brasileira de Fruticultura 32: 577-583. 
Silva, J.A.A., Grizotto, R.K., Miguel, F.B., Bárbaro, I.M. 2011. Caracterização físico-química de frutos de clones de dovyalis (Dovyalis abyssinica Warb). Revista Brasileira de Fruticultura v. especial: 466472.

Sleumer, H.O. 1980. Flacourtiaceae. Flora Neotropica 22: 1-499.

Souza, L.V., Gentil, D.F. 2013. Estaquia da cultivar de tomateiro Yoshimatsu. Horticultura Brasileira 31: 166-170.

Ventura, T.M., Machado, N.G., Martins, A.L., Campelo Jr., J.H., Lobo, F.A., Ortiz, C.E.R., Martins, C.E.R, Martins, C.A. 2014. Temperaturas basais para o crescimento de frutos de mangueira Alfa. Bioscience Journal 30: 467-474.

Vignolo, G.K., Picolotto, L., Gonçalves, M.A., Pereira, I.S., Antunes, L.E.C. 2014. Presença de folhas no enraizamento de estacas de amoreirapreta. Ciência Rural 44: 467-472.

Wachowicz, C.M., Carvalho, R.I.N. 2002. Fisiologia vegetal e pós-colheita. Champagnat, Curitiba, Brasil. 424p. 